\title{
Impact of Public Debt on Economic Growth in Nigeria (1990 to 2019)
}

\author{
Veronica B. Edeminam \\ Department of Economics, Faculty of Social Sciences, Nile University of Nigeria, 900001, Abuja, Nigeria
}

Received May 24, 2021; Revised June 29, 2021; Accepted July 25, 2021

\section{Cite This Paper in the following Citation Styles}

(a): [1] Veronica B. Edeminam, "Impact of Public Debt on Economic Growth in Nigeria (1990 to 2019)," Advances in Economics and Business, Vol. 9, No. 1, pp. 1 - 10, 2021. DOI: 10.13189/aeb.2021.090101.

(b): Veronica B. Edeminam (2021). Impact of Public Debt on Economic Growth in Nigeria (1990 to 2019). Advances in Economics and Business, 9(1), 1 - 10. DOI: 10.13189/aeb.2021.090101.

Copyright $\bigcirc 2021$ by authors, all rights reserved. Authors agree that this article remains permanently open access under the terms of the Creative Commons Attribution License 4.0 International License

\begin{abstract}
This study examines the impact of public debt on economic growth in Nigeria using annual time series data from 1990 to 2019 collected from Central of Nigeria statistical bulletin. The variables are Real GDP, public debt, Inflation, debt to GDP ratio, debt servicing to GDP ratio, and exchange rate. Empirical analysis was conducted using Augmented Dickey Fuller unit root test to check for stationarity. Johansen Cointegration test was used to determine long run relationship and Vector Error Correction Model to check for short run and long run impact of public debt on economic growth. Empirical results showed that the impact of public debt on economic growth was negative and significant in the long run. The impact of public debt on economic growth was negative but insignificant in the short run. In addition, the impact of ratio of debt servicing to GDP was significant and negative in the short and long run. There was no causality between public debt and economic growth. The study recommends that public authorities in Nigeria should reduce reliance on public debt and instead move towards increasing revenues through diversification of the export base of the economy and expanding the tax net. The study also recommends strengthening public institutions so that revenues collected, in the form of debt or other means can be adequately utilized on investments that are efficient.
\end{abstract}

Keywords Public Debt, Economic Growth, Debt Servicing

\section{Introduction}

Nigeria, with an estimated population of over 206.5 million people according to United Nations data is ranked as the country with the highest population in Africa and the 7th in the world [1]. A nominal GDP of \$448 billion makes it the largest economy on the African continent. Nigeria, despite being blessed with enormous resources, faces a plethora of socio-economic issues. These issues are often attributed to inefficient management of the economy and public finances by successive governments.

Currently, there is constant debate across academic and government corners on topics of macroeconomic management and public finance. At the very fore of these debates is the important issue of public debt. Debt is pertinent to economic growth and national development because it provides immediate bulk cash necessary for capital-intensive projects, the costs of such projects will tighten the fiscal space in the economy if sourced from government coffers [2]. Debt also allows the government to undertake countercyclical fiscal policy in times of economic recession. Other forms of debt such as venture capital and project finances expedite the execution of projects because it eliminates the delays caused by bureaucratic processes associated with government financing mechanisms. Despite the aforementioned merits, mismanagement of debt is detrimental to the economy as it creates debt traps capable of straining limited resources for extended periods of time [3]. Also, rising debt could lead to uncertainty among citizens about the economic outlook in the future because of expectations of future tax increases and government expenditure cuts in order to repay the debt [42].

Experts hold very diverse positions on Nigeria's debt situation. The first group maintains that a debt issue is non-existent at the moment because at $\$ 79$ billion, the 
debt to nominal GDP ratio is a paltry $23 \%$ which is lowest amongst economies of the same category as Nigeria [4]. The second group highlights that when the debt is analyzed using real GDP, the debt to GDP ratio of $29 \%$ already surpasses the acceptable threshold dictated by the fiscal responsibility act which is a maximum of $25 \%$ [5]. Also the group explains the debt situation from the servicing perspective where about $70 \%$ of total revenue and $40 \%$ of the national budget is directed towards debt servicing, this perspective could be indicative of an alarming debt problem [6].

This research is motivated by the lack of consensus on the impact of public debt on economic growth in Nigeria. The research findings will be useful to determine whether public debt has improved short run and long run economic growth and especially for policy makers to make decisions regarding incurring more public debt for the future. This research will add to the body of literature on the impact of public debt on economic growth with particular focus on Nigeria.

In developing countries, policy makers and international organizations often give far less attention to domestic debt as compared to external indebtedness [8]. The study of the impact of domestic debt is important because domestic debts can have crowding-out effects on private demand [8]. Governments use domestic private savings meant for private sector lending when they borrow domestically, and this results to reduced private investment demand [8]. Furthermore, high yielding government domestic debt held by banks can make them self-satisfied about costs and complacent to mobilise deposits for funding private sector projects $[8,9]$.

The main objectives of this study is to describe the trend of public debt and economic growth in Nigeria. The specific objective is to empirically investigate the impact of public debt on economic growth in Nigeria from 1990 to 2019. This study will focus on domestic and foreign debts owed by the federal and subnational governments in Nigeria. Subnational government debt is also added to the study because the federal government guarantees the subnational government debts. Thus, subnational government debt is also a liability for the federal government. Furthermore, the timing of this study is significant given the low government revenues presented by the COVID - 19 pandemic and the increased need for the federal government to borrow more funds to increase spending and stimulate aggregate demand [10].

\section{Literature Review}

\subsection{Theoretical Review}

The classical theorists argue that public debts distorts private capital from productive function to non-productive uses, which affects capital accumulation, growth and economic development $[11,12,13]$. This is because the public sector is not efficient and debt leaves a great burden on the next generations [13].

Adolf Wagner admits that public debt is acceptable when debts are unused resources available in the economy or from abroad [13]. However, debts should not be used for recurrent expenditure. This is because public expenditure grows as the economy grows. In order for government to meet up with the increased need to provide public goods, it needs to borrow resources [14].

The Keynesian theorists argue that public borrowing is a way to correct economic imbalances and stimulate the economy on the path of economic growth $[16,15,13]$. They proposed that public debt is desirable for enhancing economic growth and reducing unemployment, in time of recession, or when the economy is stagnant [15]. They assert that budget deficits can be funded by borrowing both internally and externally. However, inflation of the domestic currency is not to be avoided [13].

From the position of the monetarist economists, public debt is a major disruptive factor and a generator of instability [17]. The negative effect of public debt is from the crowding-out effect theory which assumes that when public authorities raise public loans, the demand for loans increase while the supply of loanable funds remain unchanged. This increases the interest rate of loanable funds in the market. The private sector that is highly sensitive to changes in interest rate, reduce their demand for loanable funds and so private loanable funds go towards the public sector. This way, the anticipated positive impact of public debt on economic growth is low or even null [13].

Other theories about public debt is the debt overhang theory and the liquidity crisis theory. The debt overhang theory asserts that a country may be unable to repay its debt because of the presence of a large stock of debt [18]. A country has a debt overhang situation when its debt is higher than the expected value of future resource transfers [19]. High debt stock has a distortionary effect on investment choices and reduces economic growth [18].

The liquidity crisis theory asserts that as debt is repaid and service payments are made, this could affect investment decisions. When nominal debt is so large, the resources to be used for investment in the economy is used to repay the debts. This is worse for a country with a low level of income because budgetary outlays and tax revenues determine public investments, which are usually low [18]. The repayment of external debt is encouraged through depreciation of exchange rates. Foreign debts are repaid using export earnings and depreciation of exchange rate encourages exports. Thus, depreciation of exchange rates is expected to aid the repayment of external debts for a country with net export surplus [20].

\subsection{Empirical Review}

A summary of the studies was provided with focus on their econometric models, findings and recommendations. 
The studies reviewed influenced the choice of variables and econometric techniques utilized in the model, and shapes the A-priori expectations.

Favour et al. [21] used the Vector Error Correction Model (VECM) and Granger causality test to analyze the nexus between public debt and economic growth in Nigeria. Results indicated that domestic and external debt were significantly detrimental to the growth of Nigeria's economy between 1985 and 2015. The granger causality test showed a bi-directional relationship between the variables. The study attributed the negative findings to misallocation of borrowed funds and recommended better allocation mechanisms that will be void of corruption.

The findings of Didia and Ayokunle [22] were different from the findings of Favour et al. [21]. The study of Didia and Ayokunle [22] revealed a long run statistically significant positive relationship between domestic debt and economic growth, while external debt revealed a statistically insignificant negative relationship with economic growth. The empirical analysis of the data covering 1980 to 2016 was done using the Vector Error Correction Model and they concluded that domestic debt was more beneficial to economic growth in Nigeria than external debt. They recommended that the government should be mindful of the domestic and external debt mix in Nigeria's debt portfolio.

Analysis of the impact of public debt on economic growth in Nigeria by Michael et al. [23] saw the use of multiple regression analysis, autoregressive distributed lag and Chow breakpoint test. From the results, external and domestic debt had negative effects on GDP, but only the effect of external debt on GDP was significant. The study recommends that external debt should not be used to finance budget deficits.

Similarly, Osuma, et al. [24] used a two-stage linear regression technique to explain the relationship between internal debt, GDP, National savings and recurrent expenditure. The first stage of the regression showed that only the positive relationship between internal debt and GDP is statistically significant. The results of the second stage were slightly different because internal debt was seen to have a beneficial impact on national savings and recurrent expenditure while having a negative effect on GDP. Based on the findings, the study proposed minimization of debt.

Essien, et al. [25] employed the Vector autoregression, granger causality, impulse response and variance decomposition techniques to determine the relationship between domestic debt, public debt, GDP, lending rates, and Inflation in Nigeria. The results showed that changes in external debt had an effect on lending rates. The results further showed that external and domestic debt had no significant impact on inflation and output level. The study recommends debt with longer tenure and uniformity of borrowing plans across all tiers of government.

Assessing the impact of public debt on external reserves between 1981 and 2013 in Nigeria, Oduntan et al. [26] recommends that the government should restructure the negotiation mechanisms so it can enable us get conducive rates and payment plans. The conclusions were done based on the findings of Johansen Cointegration test and fully modified least squares technique. The results showed that public debt and broad money supply has a long run positive relationship with external reserves and economic growth.

Empirical evidence not related to Nigeria was also reviewed to show evidence from other countries. Studies carried out by Sansa [27] on the analysis of public debt on economic growth and poverty in Tanzania between 2000 to 2018 showed a negative and insignificant correlation between public debt and all the study's dependent variables (GDP and poverty). The analysis was done using multiple linear regression models. From the findings, Sansa [27] concluded that public debt has no impact on economic growth and poverty reduction in Tanzania.

Similarly, the studies of Saungweme and Odhiambo [28] on the impact of domestic and public foreign debt on economic growth in Zimbabwe between 1970 and 2017 revealed a negative impact. The analysis was done using the Autoregressive Distributed Lag approach (ARDL) and they concluded that domestic debt has more harmful effect to the Zimbabwean economy than its foreign counterpart.

The possibility of positive outcomes between public debt and economic growth lies in the effort of the government to maintain a low budget deficit, low debt to GDP ratio and the use of debt for capital projects [22]. In support of this, Owusu-Nantwi and Erickson [29] while examining the impact of public debt and economic growth in Ghana, discovered a positive and statistically significant relationship between public debt and economic growth in Ghana, for the period 1970 to 2012. This was due to the ability to maintain a low debt to GDP ratio over the years.

Another study carried out by Kharusi and Ada [30] revealed a negative and significant influence of external debt on economic growth in Oman. They investigated the relationship between external debt and economic growth in Oman from 1990 to 2015 using the Autoregressive Distributed Lag Cointegration approach. From their findings, they recommended a more productive use of external debt to impact economic growth positively. Similarly, Quddus and Hameed [31] found that public debt negatively affected the economic performance in SAARC countries in both the short and long run period.

From the reviews of existing literature, there is evidence of divergent conclusions on the actual impact of public debt on economic growth in both developed and developing economies. Many of such conclusions vary with the models and data used to derive them. However, the majority of the studies confirm the existence of a nexus, one that is negative in nature. Furthermore, while the A-priori expectations are in line with the majority of the reviewed literature, the results might be different owing to disparity in scope and methodology. In spite of 
these findings, and given the current economic situation of dwindling government revenues presented by the COVID - 19 pandemic, the government seeks to achieve rapid economic growth by continuing to access capital markets both locally and internationally for more debts. This study will be different from other studies because subnational government debts will also be included in the public debt analysis.

\section{Materials and Methods}

The study uses annual time series of Real GDP, Debt Stock, Exchange rate, debt to Real GDP Ratio, Inflation, and Debt to Real GDP ratio from 1990 to 2019. The data sources are the Central Bank of Nigeria and Debt Management office.

Since time series data could be subject to stationary problems, Augmented Dickey - Fuller (ADF) unit root test is implemented on the data to test for stationarity of the variables [30, 32]. Graphical illustration is used to achieve the broad objective of analyzing the trend of public debt in Nigeria.

To achieve the specific objective of analyzing the long run relationship of debt and economic growth, Johansen cointegration model is used. This is in line with the technique adopted by Favour et al. [21], Mbam and Emeka, [23], and Quddus and Hameed [31]. Vector Error Correction model (VECM) is used to examine the impact of debt on economic growth, this is in line with the method used by Udeh, et al. [33], Kharusi and Adah [30], Favour et al. [21]. Granger causality is used to determine the direction of causality of the variables. The econometric analysis will be run using Eviews 11 software.

\subsection{Model Specification}

The model is specified following the studies of Udeh et al. [33]. The econometric form of the model is specified as; $\mathrm{GDP}=\mathrm{f}(\mathrm{DST}, \mathrm{EXR}, \mathrm{INF}, \mathrm{DS} / \mathrm{GDP})$.

The econometric equation is stated below;

$$
\begin{gathered}
\mathrm{GDP}=\mathrm{B}_{0}+\mathrm{B}_{1} \mathrm{DST}+\mathrm{B}_{2} \mathrm{EXR}+\mathrm{B}_{3} \mathrm{INF}+\mathrm{B}_{4} \mathrm{DS} / \mathrm{GDP}+ \\
\mathrm{B}_{5} \mathrm{D} / \mathrm{GDP}+\varepsilon .
\end{gathered}
$$

Where $\mathrm{Bo}$ is the intercept, $\mathrm{B}_{1}$ to $\mathrm{B}_{5}$ are the coefficients of the exogenous variables and $\varepsilon$ is the error term. All the coefficients are expected to have negative signs. Because of differences in standard units of the variables, the econometric equation is stated in the log form below;

$$
\begin{aligned}
\log (G D P t) & =B_{0}+B_{1} \log \left(D_{S T}\right)+B_{2} \log \left(E_{t} R_{t}\right)+B_{3} I N F_{t} \\
& +B_{4}\left(D S / G D P_{t}\right)+B_{5}\left(D / G P_{t}\right)+\varepsilon_{t}
\end{aligned}
$$

The parameters are explained as follows;

$\operatorname{LogGDP} P_{t}=\log$ of Real GDP in the current period. Real GDP is the proxy for economic growth.

$\operatorname{LogDST}_{t}=\log$ of debt stock in the current period. This is a summation of foreign debts, domestic debts taken by the federal government and debts taken by the subnational governments.

$\operatorname{LogEXR} R_{t}=\log$ of real exchange rate in the current period

$\mathrm{INF}_{\mathrm{t}}=\mathrm{Log}$ of Inflation rate in the current period. CPI is the proxy for Inflation rate.

$\mathrm{DS} / \mathrm{GDP}_{\mathrm{t}}=\mathrm{Log}$ of debt servicing to GDP ratio in the current period.

$\mathrm{D} / \mathrm{GDP}_{\mathrm{t}}=\log$ of debt to GDP ratio in the current period.

$\varepsilon_{\mathrm{t}}=$ Error term in the current period

Apriori expectation is that debt impacts economic growth positively. This is because government borrows to increase spending in infrastructural development or transfer payments. The model proxied Real GDP as the endogenous variable to measure economic growth, while debt stock, exchange rate, unemployment, debt to GDP ratio, inflation rate, and debt servicing to GDP ratio represent the exogenous variables.

\section{Findings and Discussion of Results}

Nigeria sources external debts from institutions such as London club, Paris club, promissory notes, and other multilateral borrowers. Nigeria also sources external debts from bilateral and commercial lenders. The sources of domestic debts for the federal government is treasury bills, treasury certificates, federal government bonds, Sukuk bonds, FGN Bonds, and green bonds [34]. Figure 1 shows an upward trend in the movement of total debt stock. Debt stock significantly declined in 2006 because of the Paris Club debt forgiveness of 2005. From 1990 to 2004, Nigeria's total debt stock increased from 382 Billion Naira to 6.2 Trillion Naira. Within this same period, ratio of debt stock to Real GDP increased from $1.98 \%$ to $17.88 \%$. In 2006, the ratio of debt stock to Real GDP reduced to $5.51 \%$ because of the Paris club forgiveness, which reduced the debt stock to 2.2 Trillion Naira. However, from 2010, the debt stock has been increasing again from 5.2 Trillion Naira to 27 Trillion Naira in 2019. As at 2019, the debt stock to GDP ratio is $38.4 \%$. The significant increase in the debt stock from 2010 is because of the inclusion of the debts collected by the subnational governments in Nigeria. The federal government guarantees the debts collected by the subnational governments, thus the subnational government debts is a liability to the federal government [7]. Other reasons for the significant increase in public debt could be attributed to the growth in public expenditure, which is shown by the rise in real GDP. Public expenditure increases as the economy grows [14]. The global recession of 2008 was an external shock to the economy, the government had to borrow to boost the economy, and reposition it on the path of economic growth. 


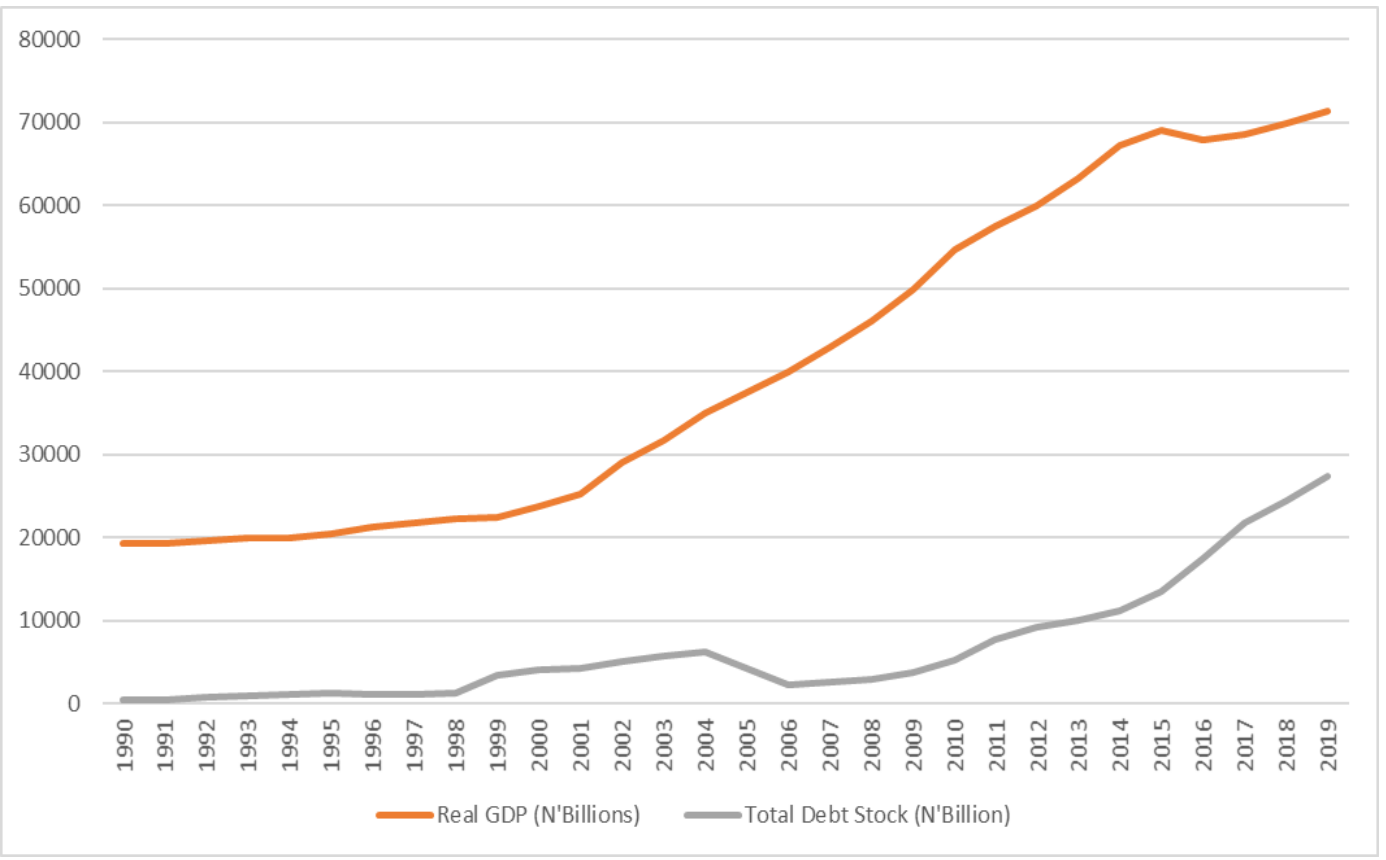

Source: Author's computation with data from CBN Statistical Bulletin 2020

Figure 1. Trend of Nigeria's Public debt and Real GDP from 1990 to 2019

Crude oil accounts for over $80 \%$ of exports and half of government revenues [35]. In 2015, the prices of crude oil fell significantly, and this affected the revenue base of the economy. Declining revenues is another possible reason for the increase in public debts in 2016. Other possible reasons for the increase in public debt in the recent years is trade arrears and exchange rate depreciation. The domestic currency value of external debts increase during depreciation and this increases the debt stock [36].

Even though the ratio of public debt to real GDP is around 29\% [34], the upward trend is worrisome because increasing debts means increasing liability to service the debts. Huge public debts might crowd out private sector investment and inhibit efforts to finance capital infrastructure [37].

\subsection{Result of Unit Root Test}

Augmented Dickey Fuller (ADF) test is carried out to test for stationarity of the variables.

A variable is non-stationary if the p-value is greater than 0.05 . The ADF test results in table $\mathbf{1}$ above show that all the variables are stationary at first difference. According to Shrestha and Bhatta [32], when all the variables are integrated of order 1 , the most appropriate method to apply is the cointegration test to establish the presence of a long run relationship either between or among the variables [38].

Table 1. ADF Test result

\begin{tabular}{ccccc}
\hline \multirow{2}{*}{ Variable } & \multicolumn{4}{c}{ Intercept } \\
\cline { 2 - 5 } & \multicolumn{2}{c}{ Level } & \multicolumn{2}{c}{ First Difference } \\
\cline { 2 - 5 } & -0.97704 & 0.7473 & -3.2911 & 0.007 \\
\hline $\log \left(G D P_{t}\right)$ & -0.94887 & 0.7576 & -3.89917 & 0.0060 \\
$\log \left(D S T_{t}\right)$ & -1.92785 & 0.3155 & -4.94685 & 0.0004 \\
$\log \left(E X R_{t}\right)$ & -2.33063 & 0.1697 & -4.43479 & 0.0016 \\
$\log \left(I N F_{t}\right)$ & 2.05709 & 0.9998 & -4.34039 & 0.002 \\
$\log \left(D S / G D P_{t}\right)$ & -1.73181 & 0.405 & -3.74859 & 0.0087 \\
$\log \left(D / G D P_{t}\right.$ & & & & \\
\hline
\end{tabular}

Source: Author's computation

\subsection{Result of Cointegration Test}

The unit root test show that all the variables are of order I(1). Johansen cointegration test is run to know if the variables are cointegrated. The test result given by Eviews shows two different statistics, Trace statistics and Maximum Eigenvalue statistics. The decision criteria is that when the trace statistic is greater than the $5 \%$ critical value, we reject the null hypothesis of no cointegration among the variables. 
Table 2. Johansen Cointegration Test Result

\begin{tabular}{|c|c|c|c|c|c|}
\hline \multicolumn{5}{|c|}{ Unrestricted cointegration rank test (Trace) } & \multirow{2}{*}{$\begin{array}{c}\text { Hypothesized no. of } \\
\text { CE(s) }\end{array}$} \\
\hline $\begin{array}{l}\text { Hypothesized no. of } \\
\text { CE(s) }\end{array}$ & Eigenvalue & Trace statistics & $\begin{array}{c}0.05 \text { Critical } \\
\text { Value }\end{array}$ & Prob. & \\
\hline None $*$ & 0.842134 & 142.9001 & 95.75366 & 0 & None * \\
\hline At most $1 *$ & 0.743034 & 91.21184 & 69.81889 & 0.0004 & At most $1 *$ \\
\hline At most $2 *$ & 0.627798 & 53.16517 & 47.85613 & 0.0146 & At most $2 *$ \\
\hline At most 3 & 0.398194 & 25.49226 & 29.79707 & 0.1446 & At most 3 \\
\hline At most 4 & 0.284578 & 11.27328 & 15.49471 & 0.1952 & At most 4 \\
\hline At most 5 & 0.065492 & 1.896574 & 3.841465 & 0.1685 & At most 5 \\
\hline \multicolumn{6}{|c|}{$*$ Rejection of hypothesis at 5 percent significance level. } \\
\hline \multicolumn{2}{|c|}{1 Cointegrating Equation(s): } & Log likelihood & -338.6292 & & \\
\hline \multicolumn{6}{|c|}{ Normalized cointegrating coefficients (standard error in parentheses) } \\
\hline RGDP & LOGDST & LOGEXR & INF & DSGDP & DGDP \\
\hline \multirow[t]{2}{*}{1} & -0.585263 & -0.29215 & -0.00536 & -42.7361 & 7.201942 \\
\hline & $(0.08913)$ & $(0.08224)$ & $(0.00131)$ & (8.1239) & $(0.77102)$ \\
\hline T-stats & 6.5663973 & 3.552456 & 4.092366 & 5.26051 & -9.3407979 \\
\hline \multicolumn{2}{|c|}{$\begin{array}{c}\text { Adjustment coefficients (standard error in } \\
\text { parentheses) }\end{array}$} & T-stats & & & \\
\hline \multirow[t]{2}{*}{ D(LOGRGDP) } & -0.009324 & 0.311007 & & & \\
\hline & $(0.02998)$ & & & & \\
\hline \multirow[t]{2}{*}{ D(LOGDST) } & 0.883187 & -3.276280 & & & \\
\hline & $(0.26957)$ & & & & \\
\hline \multirow[t]{2}{*}{ D(LOGEXR) } & 0.819148 & -2.611079 & & & \\
\hline & $(0.31372)$ & & & & \\
\hline \multirow[t]{2}{*}{ D(INF) } & 31.34438 & -2.192635 & & & \\
\hline & (14.2953) & & & & \\
\hline \multirow[t]{2}{*}{ D(DSGDP) } & 0.0016 & -0.79644 & & & \\
\hline & $(0.00197)$ & & & & \\
\hline \multirow[t]{2}{*}{$\mathrm{D}(\mathrm{DGDP})$} & 0.0478 & -1.536872 & & & \\
\hline & $(0.03108)$ & & & & \\
\hline
\end{tabular}

Source: Author's computation with data from CBN Statistical bulletin 2020. 
According to Table 2, the Trace statistics for all asterisked hypothesized number of CEs is greater than the critical value at $5 \%$, this means that we reject the null hypothesis that there is no cointegrating variables. The maximum Eigen statistics for all asterisked hypothesized number of CEs is higher than the critical value at $5 \%$, thus we reject the null hypothesis that there is no cointegration in the variables. The unrestricted cointegration rank test based on trace statistics and maximum eigenvalue both indicate that there exists one cointegration relationship. The rejection of the null hypothesis indicates the presence of long run relationships between the variables.

In the long run, the cointegration equation table shows that the ratio of debt servicing to GDP, inflation, exchange rate and debt stock has a positive relationship with real GDP other factors remaining constant. While the ratio of debt to GDP has a negative relationship with real GDP other factors remaining constant. The coefficients are statistically significant at the $5 \%$ level.

\subsection{Result of Vector Error Correction Model}

According to Shrestha and Bhatta [32], if the variables are of the order $\mathrm{I}(1)$ and there exists a cointegration relationship, the Vector Error Correction model (VECM) is the most appropriate method of analysis.

Table 3. Cointegration and EC Estimates of equations

\begin{tabular}{|c|c|c|}
\hline Coefficients & Estimates & T-stats \\
\hline \multicolumn{3}{|l|}{$\begin{array}{c}\text { Long run coefficient } \\
\text { estimates }\end{array}$} \\
\hline LOGRGDP(-1) & 1 & \\
\hline $\operatorname{INF}(-1)$ & -0.005361 & [-4.09188] \\
\hline LOG_EXR(-1) & -0.292154 & {$[-3.55249]$} \\
\hline LOG_DST(-1) & -0.585263 & {$[-6.56655]$} \\
\hline DSGDP(-1) & -42.7361 & {$[-5.26052]$} \\
\hline DGDP(-1) & 7.201942 & [ 1196.62] \\
\hline $\mathrm{C}$ & -4.837272 & \\
\hline \multicolumn{3}{|l|}{$\begin{array}{c}\text { Short run coefficient } \\
\text { estimates }\end{array}$} \\
\hline CointEq1 & -0.009324 & {$[-0.31096]$} \\
\hline D(LOG_RGDP(-1)) & 0.754234 & [ 3.45349] \\
\hline $\mathrm{D}(\mathrm{INF}(-1))$ & 0.000316 & {$[0.61131]$} \\
\hline D(LOG_EXR(-1)) & 0.037753 & [ 1.24972] \\
\hline D(LOG_DST(-1)) & -0.031145 & {$[-0.51773]$} \\
\hline D(DSGDP(-1)) & 0.021337 & {$[0.00767]$} \\
\hline $\mathrm{D}(\mathrm{DGDP}(-1))$ & 0.055038 & [ 0.10408] \\
\hline $\mathrm{C}$ & 0.011272 & [ 0.94007$]$ \\
\hline
\end{tabular}

Source: Author's computation

Based on the computations in table 3 above, the long run VECM equation can be represented as;

ECTt $-1=$ [1.0000LOG_RGDPt- $1-0.005361$ INFt -1 0.292154LOG_EXRt-1 -0.585263 LOG_DSTt-1 -

\subsection{DSGDPt-1 + 7.201942DGDPt-1 - 4.837272}

The long run coefficient estimates indicate that a percentage change in inflation will decrease real GDP by 0.0054 percent in the long run other factors remaining constant. This is in line with the studies carried out by Matandare and Tito [39] which showed that inflation has an inverse relationship with economic growth.

A percentage change in debt stock will decrease real GDP by 0.585 percent in the long run ceteris paribus. This result is in line with apriori expectation that an increase in debt stock will reduce economic growth in the long run as a result of debt overhang and liquidity crisis. The Liquidity crisis theory states that as debt stock increases, this causes a distortionary effect on investment, because government revenues that are to be used for investment purposes will be used for debt repayment [18]. Investment is a necessary requirement for capital growth, which increases economic growth [18]. This result is in line with the result of Udeh et al. [33], Kharusi and Adah [30], Matandare and Tito, [39]; Favour et al. [21].

A percentage change in exchange rate and ratio of debt servicing to real GDP will decrease real GDP by 0.292 and 42.736 percent respectively in the long run, other factors remaining constant. This is in line with apriori expectation and economic theory. The findings of Udeh et al. [33] supports this. Debt servicing reduces government revenue for investment and impacts negatively on economic growth [33]. The impact of exchange rate on GDP does not conform to apriori expectation. This is contrary to the findings of Udeh et al. [33]. A percentage change in ratio of debt to real GDP in the long run will increase real GDP by 7.20 other factors remaining constant. This result is not in line with apriori expectation. Increase in debt to GDP ratio implies increase in debt liability, and in the long run, repayment of the debt will reduce the available revenue for investment [33]. Elmendorf and Mankiw [40] posits that an increase in public debt reduces public savings, which will in turn reduce the national savings. A decline in national savings will reduce capital stock and domestic investment [33]. Also, increase in domestic debt will crowd out private investment. The t-statistics show that all the coefficients are statistically significant at the 5\% level.

Based on the computations in table 3, the short run VECM equation can be represented as;

$$
\begin{gathered}
\Delta \text { LOG_RGDPt }=-0.009324 \text { ECTt }-1+ \\
0.754234 \Delta \text { LOG_RGDPt- } 1+0.000316 \Delta \text { INFt } 1+ \\
0.037753 \Delta \text { LOG_EXRt- } 1-0.031145 \Delta \text { LOG_DSTt }-1- \\
0.021337 \Delta \text { DSGDPt- } 1+0.055038 \Delta \text { DGDPt- } 1+0.011272
\end{gathered}
$$

From the results above, the previous year's deviation from long run equilibrium is corrected at a speed of 0.0093 percent. In the short run, a percentage change in real GDP in the previous period is associated with 0.75 percent change in real GDP in the current period, ceteris paribus. A percentage change in inflation is associated 
with a 0.000316 percent increase in real GDP on average ceteris paribus in the short run. The $t$ statistics indicate that the impact of the independent variables on real GDP is not significant in the short run.

\section{Conclusion and Recommendations}

The study analysed the historical trend of total public debt in Nigeria, taking into account the federal government foreign and domestic debts, and the subnational government foreign and domestic debts. Specifically, the study examined the long run relationship between public debts and economic growth in Nigeria. The study also investigated the impact of public debt on economic growth in Nigeria.

Graphical analysis was used to describe the historical trend of public debt in Nigeria. The trend showed that economic growth has been increasing over the years together with public debt. This does not imply that public debt causes economic growth. The study utilized Johansen cointegration method to examine the long run relationship between the variables. The study also utilized Vector Error Correction method to examine impact of public debt on economic growth in Nigeria. The results of the cointegration approach showed that there is a long run relationship between public debt and economic growth. The VECM approach showed that public debt had a significant and negative impact on economic growth in the long run, in the short run however, the impact is also negative but insignificant. This could be as a result of debt overhang, and crowding out problem. This further corroborates the position of the monetarist economists that public debt is a major disruptive factor because it distorts investment decisions [17].

Considering that Nigeria is a developing economy, the study recommends that Nigeria should diversify the revenue base of the economy in order to attract more income to cover budget deficit gap. Internally, tax administration should be strengthened to increase the tax to GDP ratio of the country. The tax to GDP ratio currently stands at around 5\% [41]. Increasing the tax-to-GDP ratio to around $20 \%$ will close the fiscal deficit gap and provide the needed resources for government expenditures. Externally, the export base of the economy should be diversified. Mismanagement of debts is as a result of weak institutions of monitoring and control, thus public institutions for monitoring and implementation of debt should be strengthened so that debts collected can be used for intended purposes. Debt Management Office should also put mechanisms in place to ensure that debts are used for productive purposes. Data sources from Debt Management Office [7] show that debts collected for infrastructural projects are already being serviced annually even before the projects are completed and commissioned. Some of these projects take years to complete, but the debts are serviced for the years when the projects are still under construction and not producing any returns. The federal government should consider the option of negotiating for debts servicing and installmental capital repayment after an infrastructural project is completed and commissioned, for project based loans. This will ensure that the creditors put in more efforts to complete the projects in a timely manner. On the part of subnational debts, conditionalities should be attached to the subnational debts. Subnational governments must meet those terms before the federal government would guarantee its debts.

The graphical analysis in figure 1 showing the same trend movement of public debt and economic growth could mean that it is actually economic growth that is resulting to more public debt. This is an area for further research that should be explored.

\section{Acknowledgements}

I am grateful to His Holiness Olumba Olumba Obu, the Fountain of Knowledge for His guidance throughout the research. I am grateful for Anthony Akpasoh for his support throughout this research. I am very grateful to Haruna Abdullahi who read through and gave feedback on the draft. I am also grateful to the team of reviewers for their feedback.

\section{REFERENCES}

[1] United Nations, "United Nations World Population Prospects: The 2019 revision, https://population.un.org/wpp/ (accessed Dec. 20, 2020).

[2] Sosvilla-Rivero, S., and Gomez-Puig, M. "New Empirical Evidence on the Impact of Public Debt on Economic Growth in EMU Countries". Revista de Economia Mundial, 51, 101-120, 2019.

[3] Filip, B. F. "Determinants of public debt. The case of the European Union countries". Theoretical \& Applied Economics, Asociata Generala a Economistilor din Romania - AGER, vol. 0 (special), pp. 61 - 70, 2019.

[4] Debt Management Office, "Nigeria's Total Public Debt Portfolio as at March 31st, 2020". https://www.dmo.gov.ng/debt-profile/total-public-debt/323 5-nigeria-s-public-debt-stock-as-at-march-31-2020/file (accessed Jan. 5, 2021).

[5] Trading Economics. "Nigeria Government Debt to GDP". https://tradingeconomics.com/nigeria/government-debt-togdp (accessed Jan. 10, 2021).

[6] Federal Ministry of Budget and National Planning, "Nigeria Appropriation Bill. Abuja: Ministry of Budget and National Planning, " 2020.

[7] Debt Management Office. Subnational Borrowing 
Guidelines. https://www.dmo.gov.ng/facts-about-chinese-1 oans-to-nigeria (accessed Dec. 26, 2020).

[8] Akram, N, "Impact of Public Debt on the Economic Growth of Pakistan," The Pakistan Development Review, vol. 50, no. 4, pp. 599-615, 2011. http://www.jstor.org/stable/23617723

[9] Hauner, D. "Fiscal Policy and Financial Development". International Monetary Fund Working paper No. 06/26, 2006.

[10] Nigeria Economic Sustainability Plan. "Bouncing Back: Nigeria Economic Sustainability Plan". https://media.premiumtimesng.com/wp-content/files/2020/ 06/ESC-Plan-compressed-1.pdf (accessed Jan 3, 2021).

[11] Smith, A, "An enquiry into the Nature and Causes of the Wealth of Nations". 5th Ed, Methuen and Co. Ltd, 1904.

[12] Ricardo, D, "On the principles of political economy and taxation," In. The works and correspondence of David Ricardo (Ed. P. Straffa \& M.H. Dobb), Vol. 1, Indianopolis: Liberty Fund. 2005.

[13] Bilan, I, "Overview of the Main Theories on the Economic effects of Public Indebtedness, " EIRP Proceedings, Vol. 11 2005.http://www.proceedings.univ-danubius.ro/index.php/ eirp/article/view/1735

[14] Irshad, C. V, "Theories of Public Expenditure, " https://hubpages.com/education/Theories-of-Public-Expen diture (accessed Dec 20, 2020)

[15] Filip, Gh, "Finanţe publice/ Public finance,” Iaşi: Junimea Publishing House. 2010.

[16] Keynes, J.M, "Activities 1931-1939. World Crises and Policies in Britain and America, " The Collected Writings of John Maynard Keynes, Vol. 21, London: Macmillan. 1982.

[17] Friedman, M, "Capitalism și libertate/ Capitalism and freedom". Bucharest: Editura Enciclopedică. 1995.

[18] Anone, M., Bandiera, L., \& Presbitero, A. F, "External debt sustainability: Theory and empirical evidence, " Catholic University of Piacenza Economics Working Paper, No. 33, pp. 1-47, 2005.

[19] Krugman, P, "Financing vs Forgiving a debt Overhang". Journal of Development Economics, vol. 29, pp. 253-268. 1988. DOI: https://doi.org/10.3386/w2486

[20] Khan, M. S., and Knight, D. M, "Import Compression and Export Performance in Developing Countries," Review of Economics and Statistics, Vol 70, No 2. Pp. 315 - 321, 1988. DOI: https://doi.org/10.2307/1928316

[21] Favour, O., Adeniyi, S., Obed, E., and Charity, A, "Public Debt and Economic Growth in Nigeria," Asian Research Journal of Arts and Social Sciences, 1-16. 2019.

[22] Didia, D., \& Ayokunle, P, "External Debt, Domestic Debt and Economic Growth: The Case of Nigeria, " Advances in Economics and Business, vol. 8, no. 2, pp. 85-94, 2020. DOI: https://doi.org/10.13189/aeb.2020.080202

[23] Michael, E., Mbam, N., \& Emeka, A, "Public Debt and Nigeria's Economic Growth, " Journal of Economic and Finance. Volume 10, 22-40. 2019.
[24] Osuma, G., Isibor, A., Adesina, T., and Abiola, B, "The Effect of Public Debt on Economic Growth in Nigeria: An Empirical Investigation, " Journal of International Business Management, vol. 12, no. 6, pp. 436-441. 2017.

[25] Essien, S., Agboebulem, N., Mba, M., \& Onumonu, O. (2016). An Empirical Analysis of the Macroeconomic Impact of Public Debt in Nigeria. CBN Journal of Applied Statistics, vol. 21, no. 7, 2016.

[26] Oduntan, E., Uzoma, O., Senibi, E., \& Oluwaseun, A, "Public Debt and External Reserve: The Nigerian Experience," Economics Research International, 7, 2016. DOI: https://doi.org/10.1155/2016/1957017

[27] Sansa, N. A., "Analysis of the Impact of Public Debt on Economic Growth and Poverty in Tanzania". Electronic Research Journal of Social Sciences and Humanities, Vol, 2, no. 1 , pp. $154 \quad$ - 167, 2020. DOI: https://doi.org/10.2139/ssrn.3567844

[28] Saungweme, T., and Odhiambo, N. M., "Sovereign Debt and Economic Growth nexus in Zimbabwe: A dynamic multivariate causality test, " Working papers 26714, University of South Africa, Department of Economics, 2020.

[29] Owusu - Nantwi, V., \& Erickson, C., "Public debt and economic growth in Ghana," African Development Review, Vol. 28, No. 1, pp. 116-126, 2016. DOI: https://doi.org/10.1111/1467-8268.12174

[30] Kharusi, S., and Ada, M., "External Debt and Economic Growth: The Case of Emerging Economy, " Journal of Economic Integration, Vol. 33, No. 1, pp. 1141-1157, 2018. DOI: https://doi.org/10.11130/jei.2018.33.1.1141

[31] Quddus, M. A., and Hameed, M. R., "Impact of High and Growing Public Debt on Economic Growth in SAARC Countries: An Econometric Analysis," Journal of Political Studies, Vol 27, Issue 1, pp. 125-142, 2020.

[32] Shrestha, B., and Bhatta, G. R, "Selecting appropriate methodological framework for time series data analysis". The Journal of Finance and Data science. Vol. 4, Issue 2, pages $71-89$. ISSN $2405-9188,2018$. DOI: https://doi.org/10.1016/j.jfds.2017.11.001

[33] Udeh, S. N., Ugwu, J. I., \& Onuka, I. O., "External debt and economic growth: The Nigeria experience, " European Journal of Accounting Auditing and Finance Research, Vol 4, No. 2, pp. 33-48, 2016.

[34] Urama, N. E., Ekeocha, Q., \& Iloh, E. C., Nigeria's debt burden, Implication for Human Development. AfriHeritage Policy brief, https://media.africaportal.org/documents/Nigerias_debt_bu rden.pdf (accessed Dec 11, 2020).

[35] World Bank, "The World Bank in Nigeria," https://www.worldbank.org/en/country/nigeria/overview (accessed Dec 11, 2020).

[36] Egwaikhide, F. O., Chete, L. N., and Falokun, G. O., "Exchange rate depreciation, budget deficit and Inflation The Nigerian Experience," Nigerian Institute of Social and Economic Research. AERC Research paper 26. AERC, Nairobi, 1994.

[37] Okoye, E., "The Nigerian Debt Problem; Causes, 
consequences and option". African Banking and Finance Review, Vol 1, No. 1, 2011. DOI: http://dx.doi.org/10.2139/ssrn.1804233

[38] Adeleye, N., "Estimate Johansen Cointegration Test," https://www.youtube.com/watch?v=TB4m9M1sIJ0\&t=142 s (accessed Jan 2, 2021).

[39] Matandare, M. A. and Tito, J., "Public Debt and Economic Growth Nexus in Zimbabwe, " Journal of Economics and Sustainable Development. Vol 9, No 2, 2018.
[40] Elmendorf, D. W. \& Mankiw, N. G, "Government Debt, " in Handbook of Macroeconomics 1, part 3: pp. 1615-1669. 1999.

[41] Uzochukwu, U. A, "Broadening Nigeria's revenue base: Can little drops of Taxes make a mighty nation? " https://www.ictd.ac/blog/broadening-nigerias-revenue-base -little-drops-of-taxes-mighty-nation/ (accessed Jan 10, 2021).

[42] Mulder, M. "Public Debt and Economic Growth". BSc Thesis, Erasmus University, Rotterdam. 